\title{
Relating Cone Penetration and Rutting Resistance to Variations in Forest Soil Properties and Daily Moisture Fluctuations
}

\author{
Marie-France Jones, Paul A. Arp \\ Forest Watershed Research Centre, Faculty of Forestry and Environmental Management, University of New Brunswick, \\ Fredericton, Canada \\ Email: arp2@unb.ca
}

How to cite this paper: Jones, M.-F. and Arp, P.A. (2017) Relating Cone Penetration and Rutting Resistance to Variations in Forest Soil Properties and Daily Moisture Fluctuations. Open Journal of Soil Science, 7, 149-171.

https://doi.org/10.4236/ojss.2017.77012

Received: May 19, 2017

Accepted: July 14, 2017

Published: July 17, 2017

Copyright ( 2017 by authors and Scientific Research Publishing Inc. This work is licensed under the Creative Commons Attribution International License (CC BY 4.0).

http://creativecommons.org/licenses/by/4.0/

\begin{abstract}
Soil resistance to penetration and rutting depends on variations in soil texture, density and weather-affected changes in moisture content. It is therefore difficult to know when and where off-road traffic could lead to rutting-induced soil disturbances. To establish some of the empirical means needed to enable the "when" and "where" determinations, an effort was made to model the soil resistance to penetration over time for three contrasting forest locations in Fredericton, New Brunswick: a loam and a clay loam on ablation/ basal till, and a sandy loam on alluvium. Measurements were taken manually with a soil moisture probe and a cone penetrometer from spring to fall at weekly intervals. Soil moisture was measured at $7.5 \mathrm{~cm}$ soil depth, and modelled at 15, 30, 45 and $60 \mathrm{~cm}$ depth using the Forest Hydrology Model (ForHyM). Cone penetration in the form of the cone index $(C D)$ was determined at the same depths. These determinations were not only correlated with measured soil moisture but were also affected by soil density (or pore space), texture, and coarse fragment and organic matter content $\left(R^{2}=0.54\right.$; all locations and soil depths). The resulting regression-derived $C I$ model was used to emulate how $C I$ would generally change at each of the three locations based on daily weather records for rain, snow, and air temperature. This was done through location-initialized and calibrated hydrological and geospatial modelling. For practical interpretation purposes, the resulting $C I$ projections were transformed into rut-depth estimates regarding multi-pass off-road all-terrain vehicle traffic.
\end{abstract}

\section{Keywords}

Soil Resistance to Penetration, Cone Index, Soil Moisture, Texture, Coarse Fragments, Organic Matter, Weather Records, Hydrological Modelling, Soil Trafficability, Rutting Depth, Recreational Vehicles 


\section{Introduction}

The soil cone index $(C D)$, a measure of a soil's resistance to penetration $(M P a)$, is a commonly used soil mechanical property to determine soil strength [1] [2]. This strength generally increases with increasing clay, coarse fragment $(C F)$, and soil density $\left(D_{b}\right)$, or reduced pore space $(P S)$, but decreases with increasing soil moisture ( $M C)$ and organic matter content (OM, \%) [3] [4] [5] [6]. Hence, non-cohesive soils such as sands and sandy loams are more easily penetrated than clay soils [3] [7] [8], wet soils have low penetration resistances and the resistance to penetration is low for organically enriched soils but high for stony and frozen soils [9] [10] [11].

In practice, off-road traffic may increase soil compaction and $C I$, which negatively affects the growth of crops by way of reduced root development [8] [12] [13] [14] [15]. In urban developments, increased $C I$ due to soil compaction decreases soil infiltration of water and tree root growth [16] [17]. However, sufficient $C I$-index soil strength is needed to allow on- and off-road traffic in agriculture and forestry operations [18] [19], while off-road recreational traffic needs to be controlled to avoid soil rutting. In this, the resistance of soils to rutting is directly proportional to the ratio between tire footprint pressure and $C I$ [20] [21] [22]. The former increases with increasing vehicle weight and load and decreasing tire footprint, which-in turn-decreases with increasing tire width, wheel diameter, and decreasing tire pressure. In the field, rut depths further increase from single to multiple passes, and with slope-induced tire spinning [23].

Efforts to minimize soil rutting require reliable forecasting of off-road soil trafficability. Doing this, however, is challenging because soil and machine-use conditions may vary daily from location to location. By location, low $C I$ conditions do not last as long for sandy soils than for loams and clays. In addition, soil trafficability varies with the extent of soil freezing and thawing, especially when traffic turns thawing soils into mud [24].

The objective of this article is determining how manually derived soil $C I$ determinations change in response to weekly spring-to-winter changes in soil moisture and temperature for three contrasting soil conditions. The data so generated allowed for: 1) quantifying the relationship between $C I$ and soil $M C$; 2) emulating and interpreting the changes in soil moisture, $C I$, and rutting depth; 3) daily year-round modelling of soil trafficability by soil texture and soil depth. While machine-based cone penetration testing (CPT [25]) would be more accurate and precise, manual $C I$ determinations have the greater portability and affordability advantage for assessing how soil trafficability conditions vary from location to location across landscapes and seasons.

\section{Materials and Methods}

\subsection{Location Description}

Three forest sites in Fredericton, New Brunswick, were chosen for this study 


\section{(Figure 1, Table 1):}

1) A mixed-wood stand on sandy clay loam in a wooded section on the University of New Brunswick campus (UNB);

2) A hemlock (Tsuga canadensis) stand on a rich loam in Odell Park (OP);

3) A silver maple site (Acer saccharinum) on an alluvial sandy loam next to a fresh-water marsh within the floodplain of the Nashwaaksis stream (SM).

The two non-alluvial soils developed on grey sandstone ablation / basal till. Elevation for the three sites ranges from 6 to $70 \mathrm{~m}$ [26]. The topography varies from undulating to hilly. The upland forest vegetation is representative of the Acadian forest species, i.e., sugar maple (Acer saccharum), red maple (Acre rubrum), white birch (Betula papyrifera), balsam fir (Abies balsamea), black spruce (Picea mariana), and hemlock (Tsuga canadensis). The 1950-2017 Fredericton weather record has a mean annual temperature of $6.6^{\circ} \mathrm{C}$, with monthly means of -1.8 and $14.9^{\circ} \mathrm{C}$ for January and July, respectively. Mean annual precipitation amounts to $1100 \mathrm{~mm}$, including $250 \mathrm{~mm}$ of snow [27].

\subsection{Field Experiment}

Soil layers were described and samples were taken from two freshly dug soil pits at each of the three locations. Five soil volumetric moisture content $\left(M C_{y}\right)$ and $C I$ readings were taken manually each week from May 29, 2015 to November 2, 2015 within two circular plots ( $1.5 \mathrm{~m}$ radius) near the soil pits at each location. This was done using a Delta $\mathrm{T} \mathrm{HH} 2$ moisture meter and a Humboldt digital cone penetrometer (cone are at base $=1.5 \mathrm{~cm}^{2}$; cone angle $60^{\circ}$ ). The $M C_{V}$ readings were taken at $7.5-\mathrm{cm}$ mineral soil depth. The $C I$ readings were obtained at $15,30,45$, and $60 \mathrm{~cm}$ depths, but were not recorded where obstructed by logs, coarse roots, and surface-accumulated rocks.

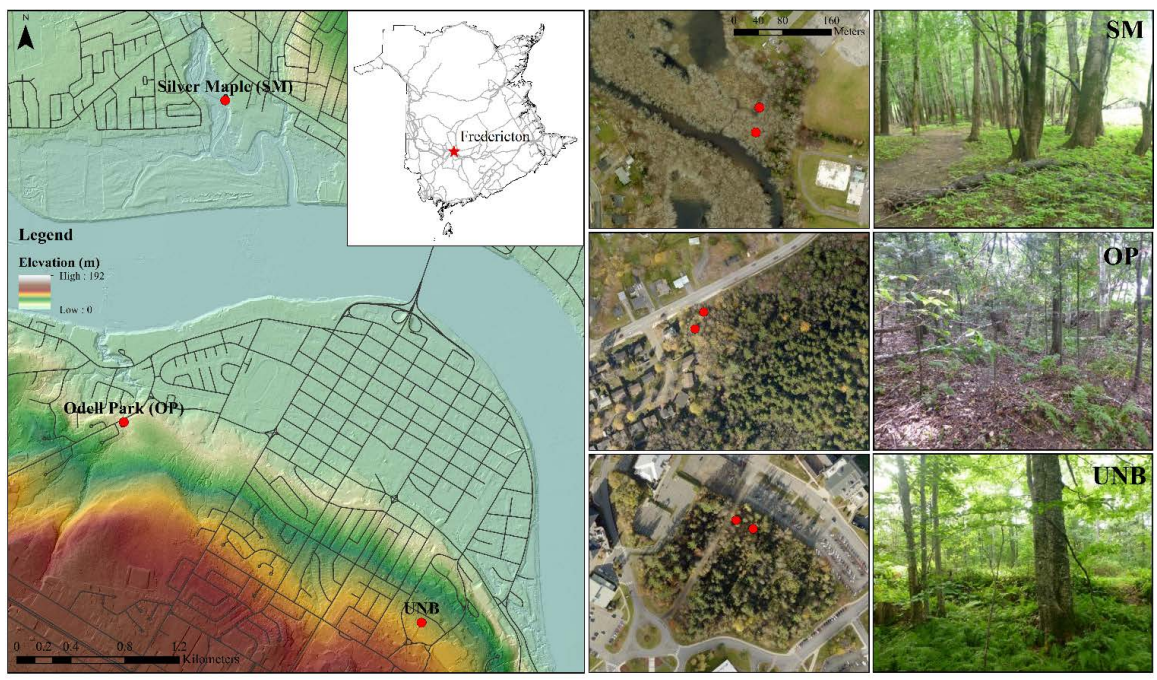

Figure 1. Overview depicting of the three Fredericton (New Brunswick) locations (left), and site-specific plot locations for $S M$ (top), $O P$ (middle), $U N B$ (bottom) (Imagery Source: Esri, DigitalGlobe, GeoEye, Earthstar Geographics, CNES/Airbus DS, USDA, USGS, AEX, Getmapping, Aerogrid, IGN, IGP, swisstopo, and the GIS User Community). 
Table 1. Location descriptions used for initializing ForHyM.

\begin{tabular}{|c|c|c|c|}
\hline Location Parameters & UNB & SM & OP \\
\hline Latitude $(\mathrm{N})$ & $45^{\circ} 56^{\prime} 40^{\prime \prime}$ & $45^{\circ} 57^{\prime} 28^{\prime \prime}$ & $45^{\circ} 58^{\prime} 46^{\prime \prime}$ \\
\hline Longitude (W) & $66^{\circ} 38^{\prime} 34^{\prime \prime}$ & $66^{\circ} 40^{\prime} 17^{\prime \prime}$ & $66^{\circ} 39^{\prime} 44^{\prime \prime}$ \\
\hline Elevation (m) & 70 & 8 & 29 \\
\hline Slope (\%) & 4.45 & 2.46 & 2.71 \\
\hline Aspect $\left({ }^{\circ}\right)$ & 30 & 132 & 24 \\
\hline $\begin{array}{c}\text { Canopy Coverage } \\
\text { Deciduous: Coniferous }\end{array}$ & $20: 40$ & 70:0 & $30: 30$ \\
\hline Rooting habit & Shallow & Deep & Shallow \\
\hline $\begin{array}{c}\text { Forest floor } \\
\text { thickness }(\mathrm{cm})\end{array}$ & 8 & 2 & 5 \\
\hline Soil Series & Sunbury / Till & $\begin{array}{c}\text { Riverbank / Glaciofluvial } \\
\text { Deposits }\end{array}$ & Sunbury / Till \\
\hline Soil Classification & $\begin{array}{l}\text { Gleyed Sombric } \\
\text { Brunisol }\end{array}$ & Gleyed Humic Regosol & $\begin{array}{c}\text { Orthic Humo-Ferric } \\
\text { Podzol }\end{array}$ \\
\hline Mineral soil texture & Sandy loam & $\begin{array}{l}\text { Loamy sand- Sandy } \\
\text { loam }\end{array}$ & $\begin{array}{l}\text { Silty loam- Sandy } \\
\text { loam }\end{array}$ \\
\hline Subsoil texture & Sandy loam & Loamy sand & Silty loam \\
\hline
\end{tabular}

The soil samples were placed into labeled freezer bags for storage. Prior to analysis, the samples were dried in a forced-air oven $75^{\circ} \mathrm{C}$ for 24 hours, crushed with a mortar and pestle, and passed through a $2-\mathrm{mm}$ sieve to remove and to determine the $C F$. The fine-earth fraction was used to determine its sand, silt, and clay content using the hydrometer method [28]. The soil carbon content ( $C$ ) of this fraction was determined using a LECO CNS-2000 analyzer. Soil $O M$ content was estimated by weight by setting $O M_{g} \%=1.72 \times C \%$. The pore-space filled moisture content $\left(M C_{p s}\right)$ was inferred by assuming that soil gravimetric moisture content $\left(M C_{g}\right)$, soil bulk density $\left(D_{b}\right)$ and the $P S$ percentage would be affected by depth and $O M$ content as follows [3]:

$$
\begin{gathered}
D_{b}=\frac{1.23+\left(D_{p}-1.23\right) \times[1-\exp (-0.0106 \times D E P T H)]}{1+6.83 \times O M_{W}} \\
M C_{g}=M C_{v} \times D_{b} \\
M C_{p s}=\frac{M C_{v}}{P S}
\end{gathered}
$$

where $D_{p}$ is particle density $\left(2.65 \mathrm{~g} / \mathrm{cm}^{3}\right)$, and $P S$ is the pore space fraction of the fine earth.

\subsection{Hydrological Modelling}

The forest hydrology model (ForHyM) [29] [30] [31] was used to emulate the changes in daily soil moisture, soil temperature and snowpack conditions for 
each of the three locations from 2006 to 2017. Doing this involved compiling the daily Fredericton weather records for air temperature, precipitation (rain, snow), stream discharge, and open-ground snow depth [27] [32]. Also specified were elevation, slope, aspect, and extent of forest cover (Table 1). The model-internal water and heat flow parameters pertaining to soil permeability, thermal conductivity, and heat capacity were plot-adjusted by texture, $O M$ and $C F$ content (Table 2), and by comparing actual with modeled soil moisture content. This was done through manually resetting the default values for: 1) the air-to-snowpack heat-transfer coefficient; 2) the initial snowpack density of freshly fallen snow to reflect the open-ground conditions at the weather station [33]; and 3) the lateral soil permeability to account for lateral flow tortuosity [34] [35]. These adjustments ensured that the model output conformed to actual snowpack depth and stream discharge records.

\subsection{Data Analysis and Model Projections ( $M C_{v}, C I$, Rut Depth)}

The data and ForHyM estimates for $M C_{v}, C I$, texture, $C F, O M, D_{b}$, and $P S$ were entered into a spreadsheet by location, date, and soil depth. This compilation served 1) to generate basic statistical summaries, 2) to analyze the measured and modelled time-series plots for $M C_{V}$ and $C I$, and 3) to determine the best-fitted linear and multiple regression models with $C I$ as dependent variable, and with $M C_{V}$ (measured, modelled), soil texture, $O M, C F, P S$, and soil depth as independent variables. A linear regression model served to relate measured $C I$ at 15,30 , 45 and $60 \mathrm{~cm}$ soil depth to measured and ForHyM-modelled $M C_{r}$. A multiple regression model served to relate $C I$ to $M C_{\triangleright}, P S$, and $C F$ as follows:

$$
\log _{10} C I=a+b P S+c M C_{p s}+d C F
$$

where $M C_{p s}$ is the water-filled portion of the $P S$, in percent. The best-fitted model so generated was incorporated into the ForHyM model to determine how $M C_{y}$, $C I$ and rutting depths pertaining to all-terrain vehicle $(A T V)$ traffic would vary over time at each of the three locations. The equations adopted for rut modelling were as follows [4] [36]:

Potential rut depths for $\mathrm{n}$ passes:

$$
R D_{n}=\left(\frac{1656}{N C I}\right) n^{\frac{1}{2}}
$$

with $N C I$ (the nominal cone index) given by:

$$
N C I=-\frac{1000 C I b d}{W} \sqrt{\frac{\delta}{h}} \frac{1}{1+2 d}
$$

where $b$ is tire width $(\mathrm{m}), \mathrm{d}$ is tire diameter $(\mathrm{m}), \mathrm{h}$ is section height $(\mathrm{m}), \delta$ is tire deflection $(\mathrm{m})$ given by $0.008+0.001(0.365+170 / p)$, $p$ is tire inflation pressure $(\mathrm{kPa}), W$ is vehicle weight + load $(\mathrm{kN})$ per wheel, and $\mathrm{n}$ is number of vehicle passes along the same track. Potential rutting depths for all-terrain recreational vehicle $(A T V)$ traffic were determined using the following machine specifications: number of wheels $=4 ; W$ per wheel $=3.1 \mathrm{kN} ; b=0.254 \mathrm{~m} ; d=0.62 \mathrm{~m}$; $h=0.3 \mathrm{~m} ; p=34.4 \mathrm{kPa} ; n=10$ passes. 
Table 2. ForHyM initialization requirements by soil layer per plot and location.

\begin{tabular}{|c|c|c|c|c|c|c|c|c|c|}
\hline Location & Plot & Layers & Depth $(\mathrm{cm})$ & Sand (\%) & Clay (\%) & Silt (\%) & OM (\%) & CF (\%) & Rooting \\
\hline \multirow[t]{10}{*}{ UNB } & 1 & LF & $-8-0$ & & Organic & & 100 & 0 & Plentiful fine \\
\hline & & $\mathrm{Ah}$ & $0-15$ & 43 & 14 & 43 & 25 & 1 & Plentiful fine \\
\hline & & Bmg & $15-40$ & 66 & 10 & 24 & 5 & 10 & Abundant med-fine \\
\hline & & Cxg1 & $40-70$ & 66 & 10 & 24 & 1 & 20 & Few coarse \\
\hline & & Cxg2 & $70+$ & 66 & 10 & 24 & 0 & 70 & \\
\hline & 2 & LF & $-8-0$ & & Organic & & 1 & 0 & Plentiful fine \\
\hline & & $\mathrm{Ah}$ & $0-15$ & 43 & 17 & 40 & 7 & 1 & Plentiful fine \\
\hline & & Bmg & $15-40$ & 66 & 10 & 24 & 2 & 10 & Abundant med-fine \\
\hline & & Cxg1 & $40-70$ & 66 & 10 & 24 & 1 & 20 & Few coarse \\
\hline & & Cxg2 & $70+$ & 66 & 10 & 24 & 0 & 50 & \\
\hline \multirow[t]{10}{*}{ SM } & 1 & $\mathrm{~L}$ & $-2-0$ & & Organic & & 100 & 0 & \\
\hline & & $\mathrm{Ah}$ & $0-15$ & 48 & 17 & 35 & 10 & 0 & Abundant fine \\
\hline & & $\mathrm{Cg} 1$ & $15-65$ & 44 & 17 & 39 & 5 & 10 & Few coarse \\
\hline & & $\mathrm{Cg} 2$ & $65-105$ & 35 & 18 & 47 & 0 & 15 & Few coarse \\
\hline & & $\mathrm{Cg} 3$ & $105+$ & 35 & 18 & 47 & 0 & 15 & \\
\hline & 2 & $\mathrm{~L}$ & $-2-0$ & & Organic & & 100 & 0 & \\
\hline & & $\mathrm{Ah}$ & $0-15$ & 48 & 17 & 35 & 20 & 0 & Abundant fine \\
\hline & & $\mathrm{Cg} 1$ & $15-45$ & 44 & 17 & 39 & 10 & 5 & Few coarse \\
\hline & & $\mathrm{Cg} 2$ & $45-95$ & 35 & 18 & 47 & 0 & 10 & Few coarse \\
\hline & & $\mathrm{Cg} 3$ & $95+$ & 35 & 18 & 47 & 0 & 15 & \\
\hline \multirow[t]{10}{*}{ OP } & 1 & LFH & $-5-0$ & & Organic & & 1 & 0 & Plentiful fine \\
\hline & & Ahe & $0-15$ & 58 & 18 & 24 & 10 & 1 & Plentiful fine to med \\
\hline & & $\mathrm{Bf}$ & $15-40$ & 54 & 20 & 26 & 5 & 5 & Abundant med \\
\hline & & $\mathrm{BC}$ & $40-90$ & 54 & 20 & 26 & 1 & 10 & Few coarse \\
\hline & & C & $90+$ & 56 & 12 & 32 & 0 & 10 & \\
\hline & 2 & LFH & $-5-0$ & & Organic & & 1 & 0 & Plentiful fine \\
\hline & & Ahe & $0-15$ & 58 & 18 & 24 & 10 & 1 & Plentiful fine to med \\
\hline & & $\mathrm{Bf}$ & $15-35$ & 54 & 20 & 26 & 5 & 15 & Abundant med \\
\hline & & $\mathrm{BC}$ & $35-70$ & 54 & 20 & 26 & 1 & 15 & Few coarse \\
\hline & & $\mathrm{C}$ & $70+$ & 56 & 12 & 32 & 0 & 15 & \\
\hline
\end{tabular}

To visually represent the temporal changes in $M C$ topographically and over seasons, $M C_{p s}$ was spatially related to the depth-to-water index $(D T W)$. This as index was generated from a 1-m resolution bare-earth digital elevation model $(D E M)$ for the Fredericton area [37]. This index determines the elevation rise along the least slope path from each cell across the landscape to its nearest open-water cell corresponding to streams, lakes, rivers and open shores [38] [39]. 
Changing the upslope flow-accumulation area by channel flow initiation $(F D$, i.e., changing the amount of upstream area needed to initiate streamflow, allows for indexing $D T W$ by season. For example, $F I=4$ ha generally represents permanent stream flow at the end of summer, $F I=0.25$ ha represents the extent of ephemeral stream flow during and after snowmelt, and $F I=1$ ha represents channel flow during the transitional periods from fall to winter. The resulting $D T W$ rasters with $F I=4,1$ and 0.25 ha were used to determine how the soil moisture conditions and rutting depths would vary across the terrain associated for the three sampling locations by season. This was done by applying Equation (7) and Equation (8) [3], i.e. [40]:

$$
\begin{gathered}
M C_{P S}=1-\left[1-M C_{P S}\left(D T W_{\text {ridge }}\right)\right] *\left[\frac{1-\exp (-k * D T W)}{1-\exp \left(-k * D T W_{\text {ridge }}\right)}\right]^{p} \\
R D_{n}=R D_{n, \text { ridge }}-\left[R D_{n, \text { ridge }}-R D_{n, D T W=0}\right] *\left[\frac{1-\exp \exp (-k * D T W)}{1-\exp \exp \left(-k * D T W_{\text {ridge }}\right)}\right]^{p}
\end{gathered}
$$

with $p=2, \mathrm{p}$ as soil-specific parameter ranging from 0.2 to 2 and), and $D T W_{\text {ridge }}$ (in $\mathrm{m}$ ) $\mathrm{R} D_{n, \text { ridge }}$ and $R D_{n, D T W=0}$ (in $\mathrm{mm}$ ) determined for driest and wettest parts of each.

\section{Results}

\subsection{Soil Moisture and $C I$ Measurements}

Each of the three locations showed distinct variations in soil properties, strength, and moisture readings over the course of 23 weeks. Given the plot-by-plot soil property differences-and tracking the changes in soil moisture over time-revealed that the $O P$ plots drained quickly. In contrast, the $U N B$ plots varied the most from wet to dry and back again to wet from spring to fall (Figure 2). In direct correspondence, resistance to cone penetration varied the least for the two $S M$ plots, and the most for the $U N B$ plots. These differences arose from the compacted and poorly drained sandy loam for the $U N B$ plots, the well-drained loamy sand with low $C F$ content for the $O P$ plots, and seasonally recurring flooding of the $S M$ plots (Table 1 and Table 2). The high springtime levels for $M_{\mathrm{v}}$ within the top $15-\mathrm{cm}$ soil at the $U N B$ and $S M$ locations are due to high Ah-layer $O M$ content, which-according to Equation (1)-lowers $D_{b}$ and enhances the soil-filled $P S$ between the coarse fragments.

Plotting the $C I$ measurements at $15 \mathrm{~cm}$ depth to the $M C_{V}$ measurements revealed that the log-transformed $C I$ and $M C_{V}$ values are linearly related to one another as shown in Figure 3 (left), as follows:

$$
\log _{10} C I_{15 \mathrm{~cm}}=0.62( \pm 0.07)-0.52( \pm 0.05) \log _{10} M C_{v}+0.20( \pm 0.03) U N B
$$

$R^{2}=0.60, R S M E=0.13, M A E=0.10$, with the $U N B$ location coded 1 and 0 otherwise. Similarly similar strong correlations between $M C$ and $C I$ have been reported elsewhere [5] [41] [42]. With respect to increasing soil depth-and as 

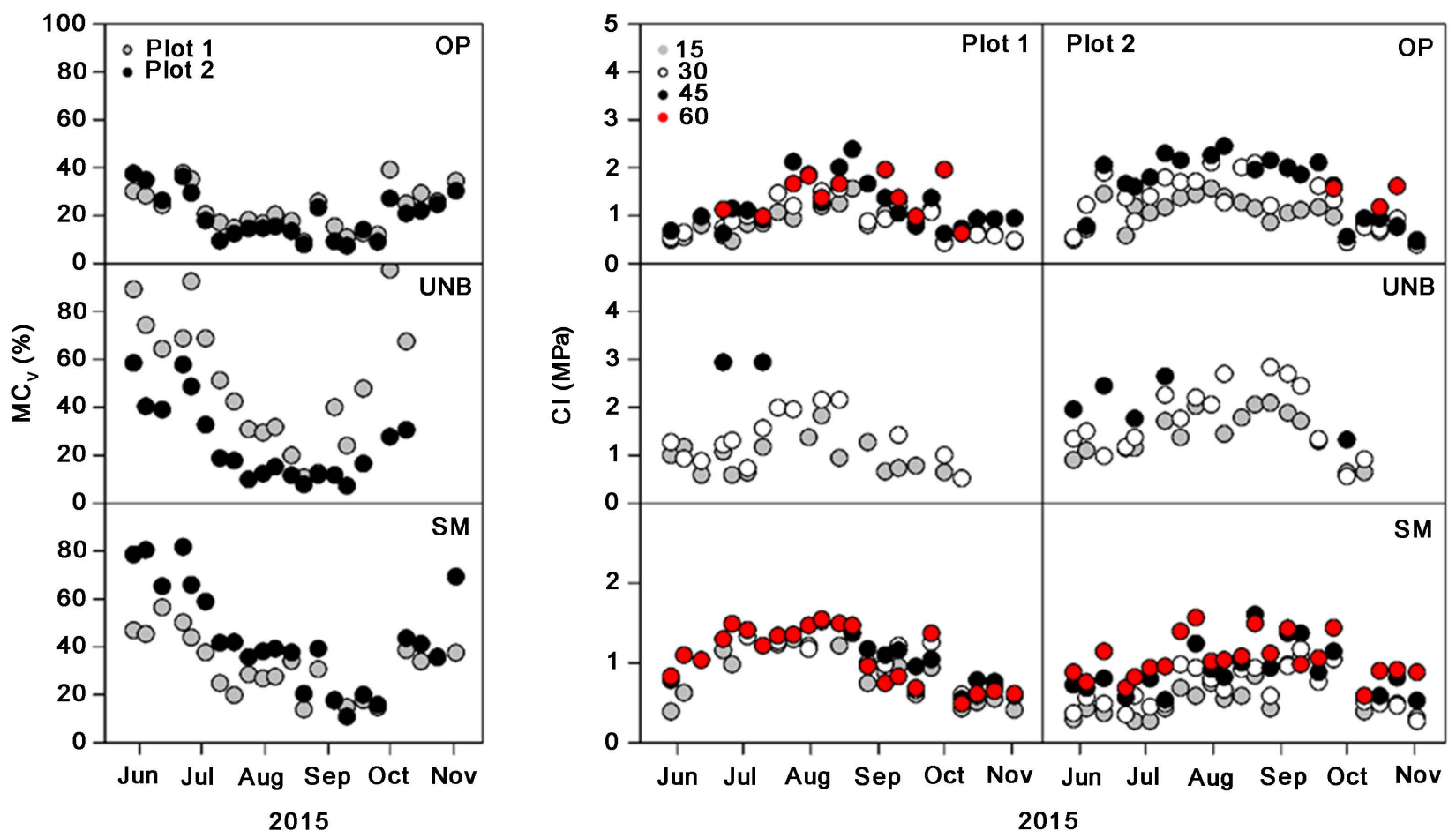

Figure 2. Left: Measured $M C_{V}$ for the top $15 \mathrm{~cm}$ of soil. Right: Measured $C I$ at 15, 30, 45, and $60 \mathrm{~cm}$ depth for Plots 1 and 2 at the $O P, U N B$, and $S M$ locations.
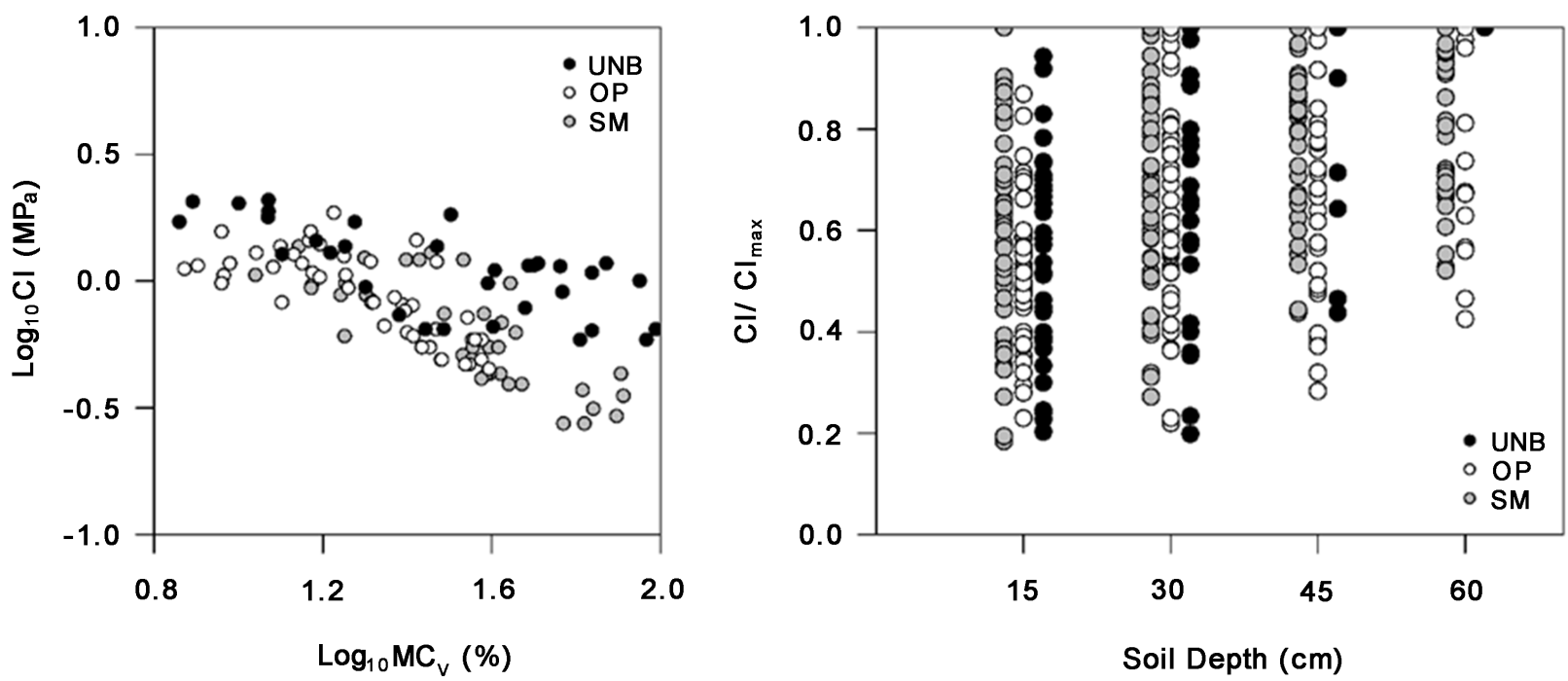

Figure 3. Scatterplots of measured $\log _{10} C I$ versus measured $\log _{10} M C_{V}$ (left), and weekly of $C I / C I_{\max }$ averages for the $O P$, $U N B$, and $S M$ locations (right).

shown in Figure 3 (right) $-C I$ increases, by plotting the ratio of the weekly averages of $C I$ over $C I_{\max }$ per plot by location. A similar trend has also been reported elsewhere [43] [44] [45].

\subsection{Soil Moisture and CI through Hydrological Modelling}

The modelling of the year-round soil moisture conditions required plot-specific 
ForHyM initializations and calibrations. These included the Fredericton-specific calibrations for snowpack depth and stream discharge required using daily Fredericton Airport weather records for rain, snow and air temperature, and adjusting the ForHyM-default settings for lateral and downward water flow, as listed in Table 3. The plot initializations in Table 1 and Table 2 refer to entering the plot- and/or layer-specific values for slope, aspect, vegetation type and cover, forest floor depth, percentages for sand, silt, clay, $C F, O M$, and layer depth.

Shown in Figure 4 are the resulting time-series plots for daily air temperature and precipitation (input), snowpack depth, stream discharge, top $15-\mathrm{cm}$ soil $M C_{V}$ (actual and modelled), and frost depth (modelled). The resulting scatter plots in Figure 5 for actual and best-fitted ForHyM snowpack depth and top $15-\mathrm{cm} M C_{v}$ (top $15 \mathrm{~cm}$ ) demonstrate a reasonable good fit, with $R^{2}=0.81$ for snowpack depth, 0.62 for stream discharge, and 0.76 for $M C_{v}$ (Table 4).

For the purpose of predicting how $C I$ would vary across time by soil texture, $D_{b}$ and $C F$ content (Table 2), it was necessary to use the ForHyM-generated depth- and time-dependent $M C_{V}$ output for the 0 - 15, 15 - 30, 30 - 45 and 45 $60 \mathrm{~cm}$ soil layers as predictor variable. Doing this involved estimating how much of the infiltrating and percolating water would be retained at any time within the fine-earth fraction between the coarse fragments of each layer. For example, the space available for water retention would decrease with increasing $C F$ content. Consequently, there would be less $P S$ to fill between the coarse fragments during wet weather conditions, and there would also be less water available for root uptake during warm summer weather [46]. This being so, The ForHyM-generated projections in Figure 6 by location and soil layer show greater $M C_{v}$ and $M C_{p s}$ variations for the stony $U N B$ location, followed by the less stony $S M$ and the more sandy $O P$ locations. In combination, the ForHyM projections in Figure 6 capture the plot-by-plot $M C_{p s}$ variations such that $O P_{M C}>S M_{M C}>U N B_{M C}$

Figure 7 and the correlation coefficients in Table 5 show how $C I$ varies with varying soil texture (Sand), $C F, O M, P S$ and $M C_{p s}$. In general, $C I$ decreases with

Table 3. ForHyM calibrations for the Fredericton area: default multipliers.

\begin{tabular}{ccc}
\hline Parameters & & Multiplier \\
\hline \multirow{2}{*}{ Snowpack } & Snow-to-air temperature gradient & 0.16 \\
& Density of fresh snow & 0.20 \\
& Surface runoff & 1 \\
& Forest floor infiltration & 1 \\
Faturated soil & Forest floor interflow & 0.05 \\
permeability & A\&B horizon infiltration & 1 \\
& A\&B horizon interflow & 0.1 \\
& C horizon infiltration & 1 \\
& C horizon interflow & 0.1 \\
& Deep water percolation & 1 \\
\hline
\end{tabular}




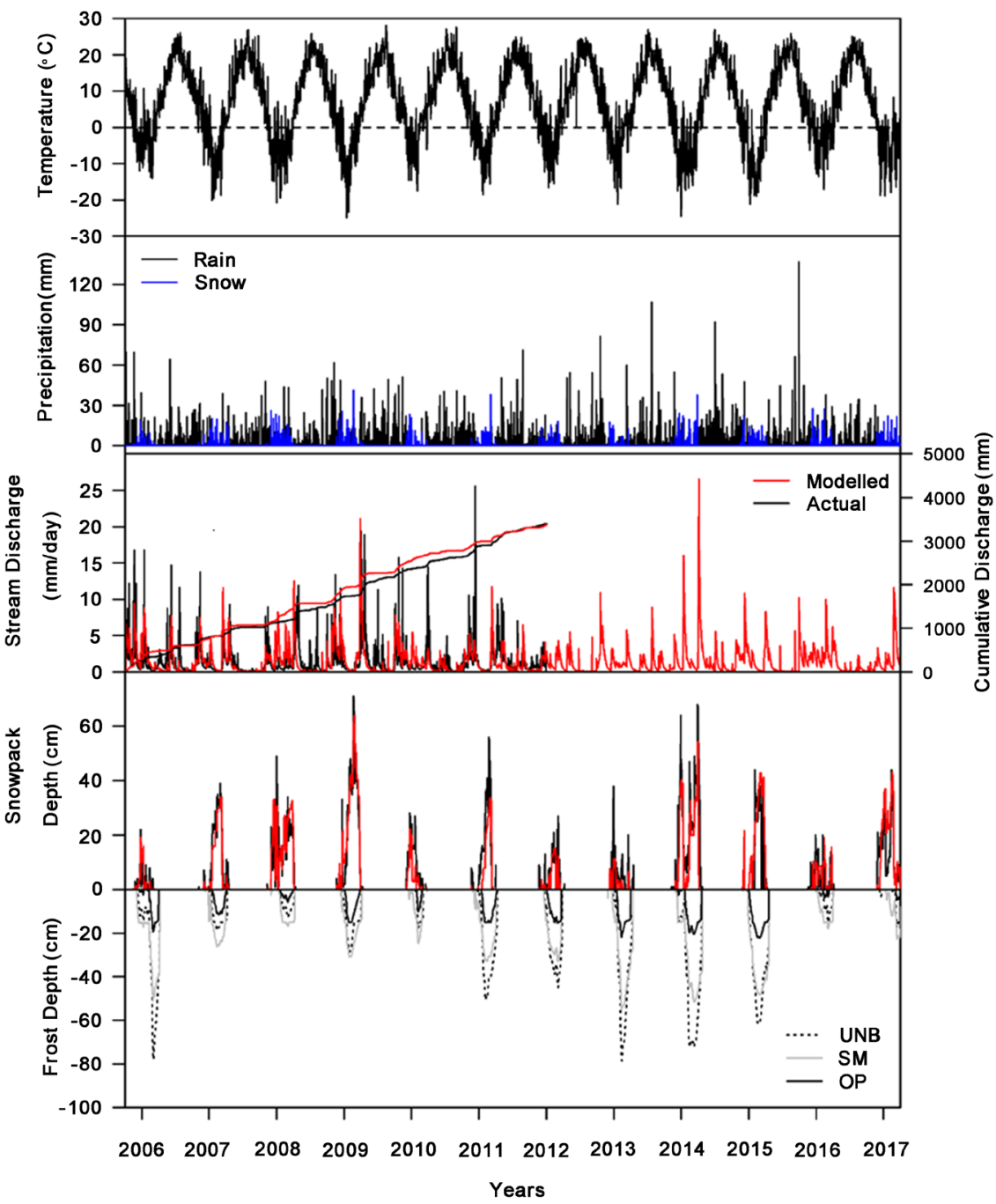

Figure 4. ForHyM time-series plots for daily air temperature and precipitation (ForHyM input), actual and modelled output for stream discharge and snowpack depth, and location-specific modelled frost depth (modelled).

increasing $P S$ and sand content due decreasing particle-to-particle contacts. Increased $O M$ content decreases $C I$ by way of soil aggregation, i.e. by further loosening the point of contact among the aggregated soil particles. The $C F$-induced increase on $C I$ refers to the increasing strength needed to displace the coarser particles away from cone penetration path [47]. Together, Sand, $O M, C F$ and $P S$ affect the daily variations in $C I$ and soil moisture retention through their combined effect on soil pore space, texture, structure and drainage [33] [48] [49].

Subjecting the correlation matrix in Table 6 to factor analysis revealed that the $C I$ variations can be grouped into three $C I$-determining factors. Factor 1 is the Location Factor, which relates a component of the $C I$ variations to the location- and layer-specific $C F$ and $P S$ determinations. Factor 2 is the Soil Moisture Factor, which relates some of the $C I$ variations to $M C_{p s}$. Factor 3 is strongly related to Sand, but-in this formulation-has no salient effect on $C I$. 


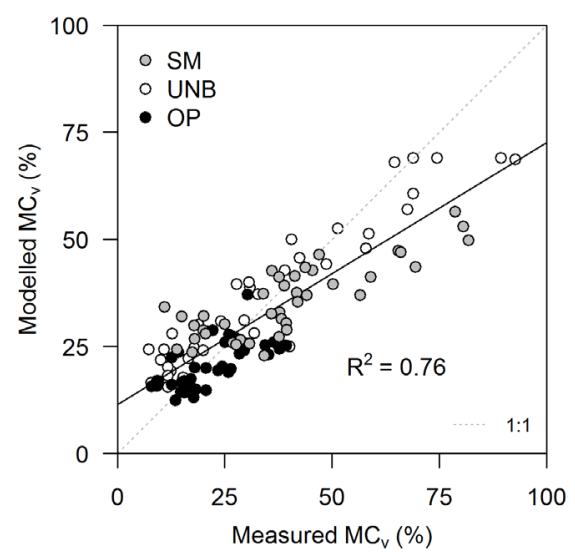

(a)

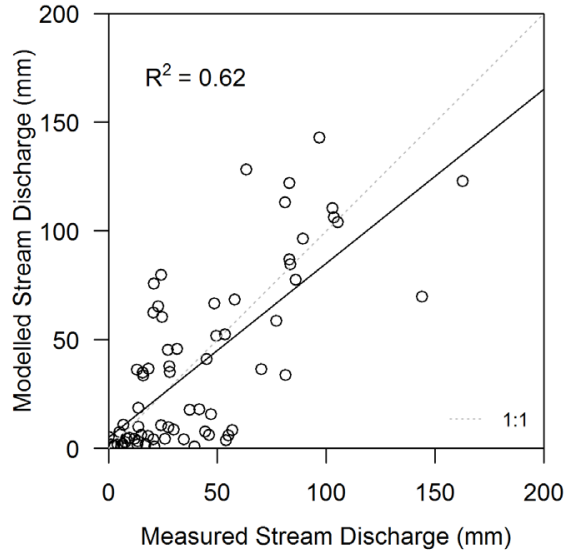

(b)

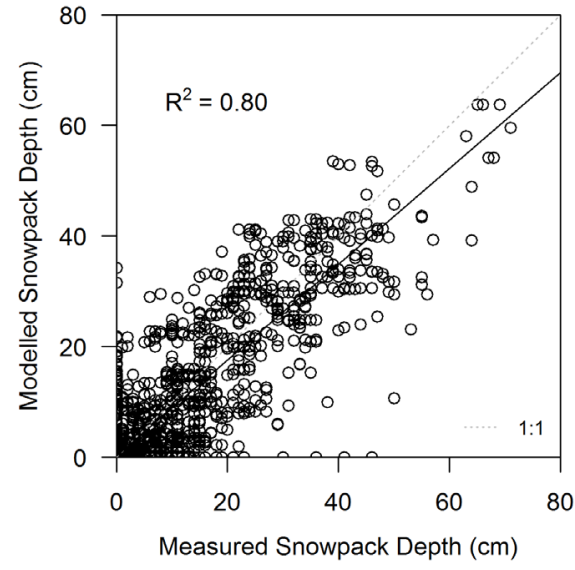

(c)

Figure 5. Actual versus ForHyM best-fitted scatter plots for $M C_{V}$ (top $15 \mathrm{~cm}$ ) (left), monthly stream discharge (middle), and daily snowpack depth (right).

Table 4. Best-fitted regression model for measured (actual) versus modelled top $15-\mathrm{cm}$ soil $M C_{V}$ by location $(U N B, S M, O P)$ and overall.

\begin{tabular}{|c|c|c|c|c|c|c|c|c|c|c|}
\hline \multirow{2}{*}{ Parameter } & \multirow{2}{*}{$\mathbf{n}$} & \multicolumn{2}{|c|}{ Intercept } & \multicolumn{2}{|c|}{ Coefficient } & \multirow{2}{*}{$t$-value } & \multirow{2}{*}{$p$-value } & \multirow{2}{*}{ Adj. $R^{2}$} & \multirow{2}{*}{$R M S E$} & \multirow{2}{*}{$M A E$} \\
\hline & & Estimate & SE & Estimate & SE & & & & & \\
\hline UNB & 37 & 13.884 & 1.690 & 0.676 & 0.039 & 17.308 & $<0.001$ & 0.90 & 5.47 & 4.50 \\
\hline SM & 41 & 20.541 & 1.816 & 0.384 & 0.041 & 9.173 & $<0.001$ & 0.67 & 4.77 & 3.91 \\
\hline $\mathrm{OP}$ & 41 & 11.694 & 1.748 & 0.415 & 0.073 & 5.717 & $<0.001$ & 0.44 & 4.01 & 3.06 \\
\hline All Sites & 118 & 11.527 & 1.191 & 0.611 & 0.032 & 19.365 & $<0.001$ & 0.76 & 6.57 & 5.48 \\
\hline
\end{tabular}

Using $P S, M C_{P s}$, and $C F$ as independent variables produced the following best-fitted multiple regression result for all soil layers and locations combined:

$$
\log _{10} C I=0.26-0.29 P S-0.41 M C_{P S}+1.04 C F
$$

$R^{2}=0.54, R M S E=0.36, M A E=0.29$. This result is illustrated in Figure 8 by way of the 3D plots, which reveal moderate $C I$ increase with decreasing $M C_{p s}$, and a rapid $C I$ increase with increasing $C F$. In reality, $C I$ and soil strength should decrease again as $M C_{p s}$ drop towards zero as the soil becomes more brittle due to reduced particle-to-particle hydrogen-bonding at low $M C[50]$. 

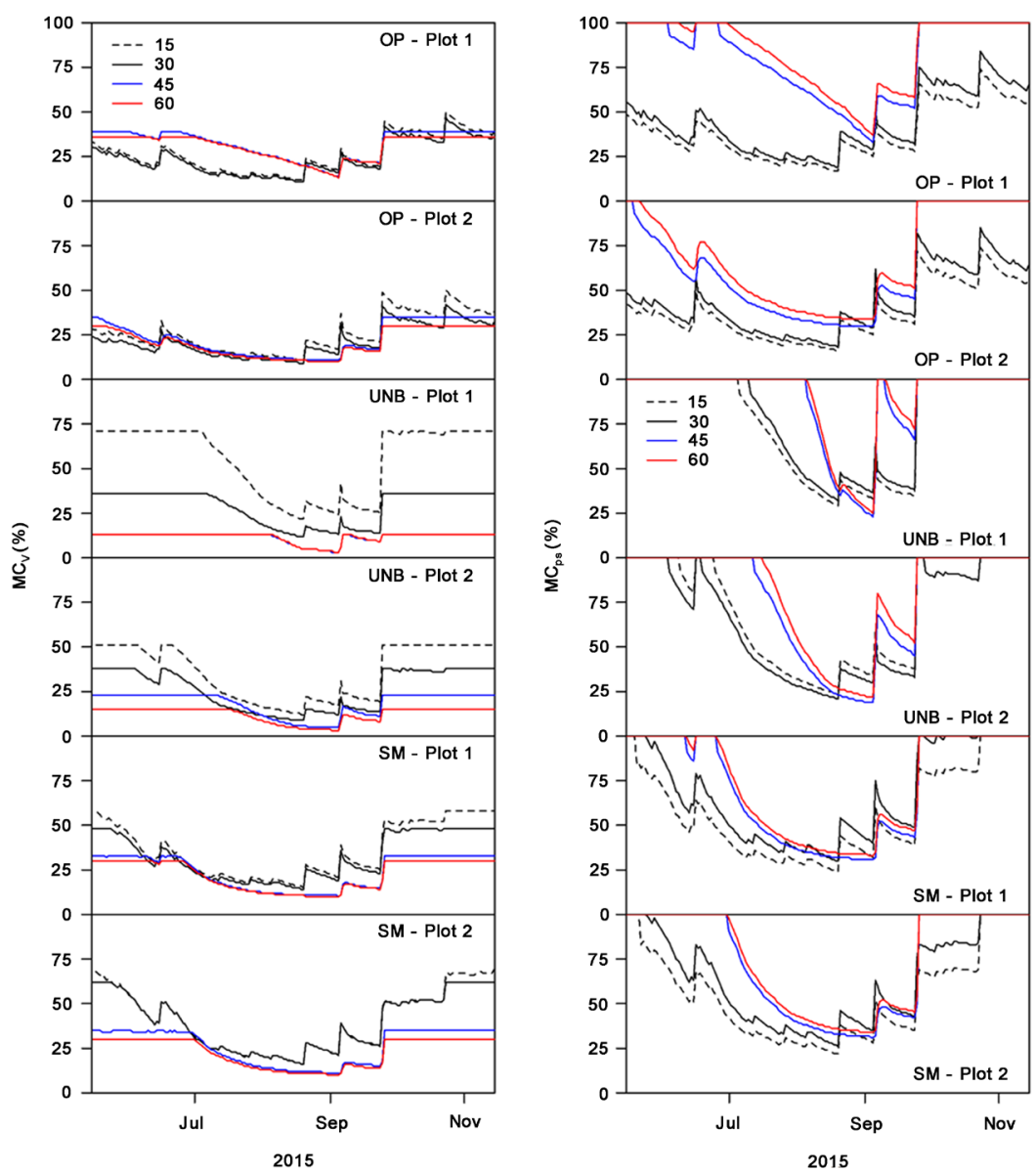

Figure 6. ForHyM-generated $M C_{V}$ and $M C_{p s}$ projection for the $0-15,25-30,30$ - 45 and $45-60 \mathrm{~cm}$ soil layers by plot and location.
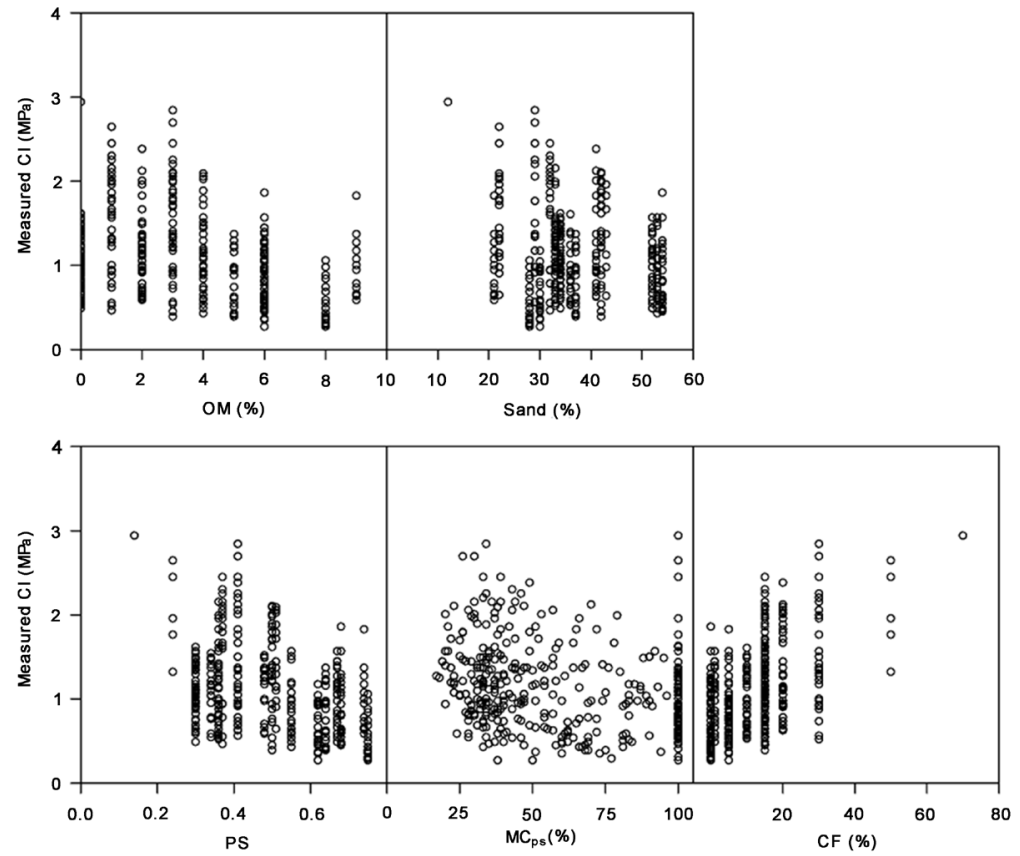

Figure 7. Plotting plot-by-plot measured $C I$ vs. $O M$, Sand, $P S, M C_{p s}$ and $C F$, showing $P S, M C_{p s}$ and $C F$ as stronger $C I$ predictor variables than $O M$ and Sand. 
Table 5. Correlation matrix for plot- and layer-determined $C I, O M$, Sand, $C F$ and ForHyM-estimated $D_{b}, M C_{v}, M C_{p s}$

\begin{tabular}{ccccccccc}
\hline Variables & $\mathrm{CI}$ & $\mathrm{MC}_{\mathrm{ps}}$ & $\mathrm{MC}_{\mathrm{v}}$ & $\mathrm{SP}$ & $\mathrm{CF}$ & Sand & $\mathrm{Db}$ & $\mathrm{OM}$ \\
\hline $\mathrm{CI}$ & 1.00 & & & & & & & \\
$\mathrm{MC}_{\mathrm{ps}}$ & -0.26 & 1.00 & & & & & & \\
$\mathrm{MC}_{\mathrm{v}}$ & -0.52 & 0.72 & 1.00 & & & & & \\
SP & -0.39 & -0.37 & 0.32 & 1.00 & & & & \\
CF & 0.55 & 0.35 & -0.18 & -0.74 & 1.00 & & & \\
Sand & -0.16 & -0.30 & -0.20 & 0.21 & -0.42 & 1.00 & & \\
Db & 0.39 & 0.37 & -0.32 & -1.00 & 0.73 & -0.20 & 1.00 & \\
OM & -0.31 & -0.31 & 0.36 & 0.97 & -0.59 & 0.07 & -0.97 & 1.00 \\
\hline
\end{tabular}

Table 6. Factor analysis of Table 5.

\begin{tabular}{cccc}
\hline Parameters & Factor 1 & Factor 2 & Factor 3 \\
\hline CI & 0.72 & 0.75 & -0.02 \\
MC $_{\text {ps }}$ & 0.18 & -0.88 & -0.26 \\
SP & -0.92 & 0.11 & -0.09 \\
CF & 0.86 & 0.03 & -0.23 \\
Sand & 0.00 & 0.15 & 1.00 \\
\hline
\end{tabular}

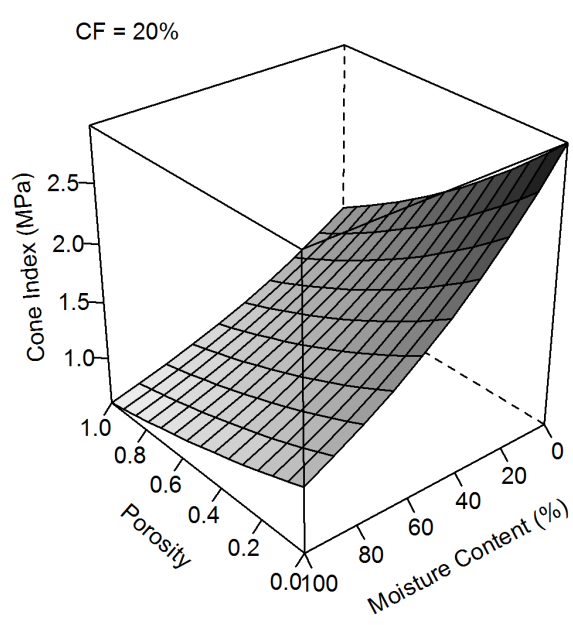

(a)

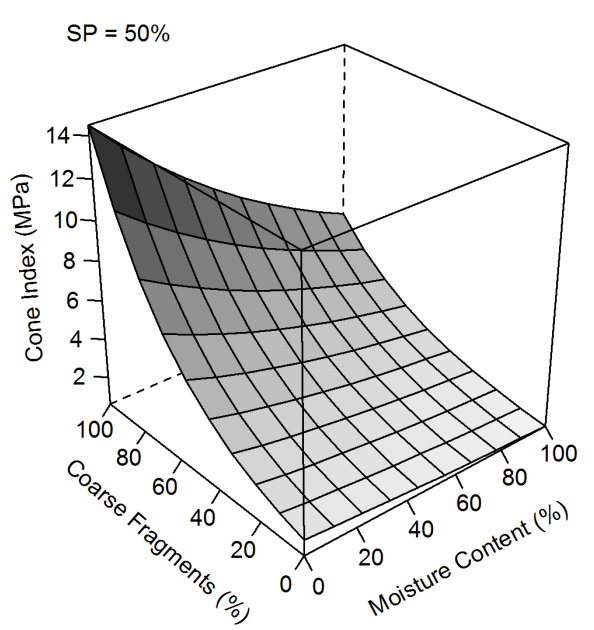

(b)

Figure 8. Modelled $C I$ (Equation (10)) in relation (a) to $M C_{p s}$ and $P S$ at $C F=20 \%$; and (b) to $C F$ and $M C_{p s}$ at $S P=20 \%$.

While Sand and $O M$ are important water retention and porosity predictor variables [51] [52], including them as part of the multiple regression process did not significantly improve the best-fitted results, likely due to the significant correlations between $O M$ and $P S$ and between Sand and $C F$ in Table 5. However, adding sampling location to the predictor variables (each location coded 1 where applicable, else 0 ) improved the best-fitted result as follows:

$$
\log _{10} C I=0.44-0.50 P S-0.39 M C_{P S}+0.69 C F-0.09 S M
$$

$R^{2}=0.60, R M S E=0.33, M A E=0.27$. This means that the $C I$ values at the $S M$ 
plots are, on average, slightly lower than at the other locations. This difference may be related to unaccounted differences pertaining to, e.g., $C F$ size (generally smaller at $S M$ than at the other two locations), and differences in rooting pattern.

Repeating this analysis by location and by soil depth produced the best-fitted results listed in Table 7. From this, it can be noted that $R^{2}$ remained about the same by location, varying from $0.41(S M)$ to $0.66(U N B)$, but decreased with increasing soil depth from 0.68 at the top to 0.10 at $60 \mathrm{~cm}$ soil depth. This decrease would mostly be due to the location-by-location $D_{b}, M C$ and $C F$ differences. This is because 1) the ForHyM-generated $M C$ estimates already take the effect of $C F$ on $M C_{p s}$ into account, and 2) the $C I$ readings become increasingly erratic when pushed through soils with increasing $C F$ content.

The dependency of $C I$ data on soil $P S, M C$ and $C F$ content was further evaluated through multiple regression analysis based on literature-generated $C I$ formulations (Table 8). The result of so doing indicated that: 1) Equation (10) provides the best data representation overall, 2) the linear formulations for $C I$ are somewhat weaker than the logarithmic formulations. Also, 3) soil porosity (or density) and $M C$ are the more persistent and significant $C I$ predictor variables than either Sand or $C F$ alone.

\subsection{Predicting Potential ATV-Caused Soil Rutting Depth}

ForHyM was used to transform the $M C_{p s}$ and $C I$ projections over time into likely ATV-generated rut depths over time from April 2013 to April 2017, using the average top 15-cm $P S$ and $C F$ values and Equation (7), Equation (8), and Equation (10) the two plots at the three sampling locations. The results are represented by the time-series plot in Figure 9. As to be expected, deepest ruts would be incurred during spring and fall, with minor blips during summer. Ruts could also be incurred during winter when some of the frozen soils would thaw due to interim warm weather and upward geothermal heat flow underneath the heat-insulating snow accumulations [53]. While trafficability advisories exist from fall to spring due to wet soil conditions, such advisories apply regionally, and therefore fall short in terms of local "when" and "where" decisions.

Table 7. Linear regression results for measured vs. modelled CI by depth and location.

\begin{tabular}{|c|c|c|c|c|c|c|c|c|c|c|}
\hline & \multirow{2}{*}{$\mathrm{n}$} & \multicolumn{2}{|c|}{ Intercept } & \multicolumn{2}{|c|}{ Coefficient } & \multirow{2}{*}{ t-value } & \multirow{2}{*}{$\mathrm{p}$-value } & \multirow{2}{*}{ Adj. $R^{2}$} & \multirow{2}{*}{ RMSE } & \multirow{2}{*}{ MAE } \\
\hline & & Estimate & SE & Estimate & SE & & & & & \\
\hline All depths & 380 & 0.010 & 0.051 & 1.040 & 0.044 & 23.13 & $<0.001$ & 0.58 & 0.34 & 0.27 \\
\hline $15 \mathrm{~cm}$ & 119 & 0.039 & 0.083 & 1.047 & 0.092 & 11.358 & $<0.001$ & 0.52 & 0.29 & 0.24 \\
\hline $30 \mathrm{~cm}$ & 114 & -0.057 & 0.093 & 1.047 & 0.075 & 13.921 & $<0.001$ & 0.63 & 0.34 & 0.28 \\
\hline $45 \mathrm{~cm}$ & 90 & -0.206 & 0.124 & 1.254 & 0.098 & 12.751 & $<0.001$ & 0.64 & 0.35 & 0.28 \\
\hline $60 \mathrm{~cm}$ & 58 & 0.528 & 0.187 & 0.5610 & 0.163 & 3.451 & 0.001 & 0.16 & 0.32 & 0.27 \\
\hline SM & 167 & 0.232 & 0.068 & 0.772 & 0.072 & 10.722 & $<0.001$ & 0.41 & 0.27 & 0.23 \\
\hline $\mathrm{OP}$ & 145 & -0.472 & 0.133 & 1.506 & 0.118 & 12.758 & $<0.001$ & 0.53 & 0.35 & 0.27 \\
\hline UNB & 69 & 0.010 & 0.135 & 1.022 & 0.088 & 11.588 & $<0.001$ & 0.66 & 0.38 & 0.31 \\
\hline
\end{tabular}


Table 8. Review of functional relationship between $C I$ and soil properties.

\begin{tabular}{|c|c|c|c|c|c|c|c|c|c|c|}
\hline \multirow{2}{*}{ Study } & \multirow{2}{*}{ Equation } & \multicolumn{6}{|c|}{ Coefficient Parameters } & \multirow{2}{*}{ Adj. $R^{2}$} & \multirow{2}{*}{ RMSE } & \multirow{2}{*}{ MAE } \\
\hline & & a & b & c & $\mathrm{d}$ & e & $\mathrm{f}$ & & & \\
\hline 1 & $\log _{10} C I=a+b P S+c M C_{p s}+c C F$ & $\begin{array}{c}0.26 \\
( \pm 0.05)\end{array}$ & $\begin{array}{c}-0.29 \\
( \pm 0.07)\end{array}$ & $\begin{array}{c}-0.40 \\
( \pm 0.03)\end{array}$ & $\begin{array}{c}1.04 \\
( \pm 0.10)\end{array}$ & & & 0.52 & 0.36 & 0.29 \\
\hline 2 & $\log _{10} C I=a+b P S+c M C_{p s}+d S$ & $\begin{array}{c}0.74 \\
( \pm 0.05)\end{array}$ & $\begin{array}{c}-0.78 \\
( \pm 0.06)\end{array}$ & $\begin{array}{c}-0.40 \\
( \pm 0.03)\end{array}$ & $\begin{array}{c}-0.31 \\
( \pm 0.09)\end{array}$ & & & 0.36 & 0.42 & 0.34 \\
\hline 3 & $\log _{10} C I=a+b P S+c M C_{p s}$ & $\begin{array}{c}0.62 \\
( \pm 0.04)\end{array}$ & $\begin{array}{c}-0.80 \\
( \pm 0.06)\end{array}$ & $\begin{array}{c}-0.37 \\
( \pm 0.03)\end{array}$ & & & & 0.33 & 0.43 & 0.34 \\
\hline 4 & $C I=a+b M C+c S+d D_{b}$ & $\begin{array}{c}2.26 \\
( \pm 0.13)\end{array}$ & $\begin{array}{c}-2.21 \\
( \pm 0.17)\end{array}$ & $\begin{array}{c}-1.50 \\
( \pm 0.24)\end{array}$ & $\begin{array}{l}-0.001 \\
( \pm 0.01)\end{array}$ & & & 0.33 & 0.42 & 0.34 \\
\hline 5 & $\log _{10} C I=a+b M C_{v}+c D_{b}$ & $\begin{array}{c}0.04 \\
( \pm 0.04)\end{array}$ & $\begin{array}{c}-0.73 \\
( \pm 0.07)\end{array}$ & $\begin{array}{c}0.12 \\
( \pm 0.02)\end{array}$ & & & & 0.35 & 0.21 & 0.16 \\
\hline 6 & $C I=a+b M+C+c D_{b}+d M C_{g}^{2}+e D_{g}^{2}+f M C_{g} D_{b}$ & $\begin{array}{c}0.92 \\
( \pm 0.43)\end{array}$ & $\begin{array}{c}-3.44 \\
( \pm 1.62)\end{array}$ & $\begin{array}{c}1.20 \\
( \pm 0.46)\end{array}$ & $\begin{array}{c}3.89 \\
( \pm 1.47)\end{array}$ & $\begin{array}{c}-0.26 \\
( \pm 0.14)\end{array}$ & $\begin{array}{c}-0.85 \\
( \pm 0.64)\end{array}$ & 0.39 & 0.42 & 0.33 \\
\hline
\end{tabular}

1: This study; 2: [4]; 3: [45]; 4: [8]; 5: [54]; 6: [55].

The extent to which soil rutting would be seasonally affected across the general neighbourhood of each of the three location was ascertained through digitally generating the elevation-derived cartographic depth-to-water index (DTW) associated with the 4,1 and 0.25 ha upslope areas for streamflow initiation [40] (Figure 10). Using these patterns in combination with Equations (7) and Equations (8) produced the spatial $M C_{p s}$ and potential ATV-related rut-depth maps in Figure 11, intended to be representative of the off-road soil trafficability conditions during spring, end of summer and the fall to winter transition. As shown, the $U N B$ location has the potential to be the most trafficable among the three locations in summer, but would be worst during spring and fall. In contrast, the $O P$ location would have the least traffic impact across the area and seasons based on texture-facilitated soil drainage. However, moderate soil rutting could occur within the 4-ha $D T W<1 \mathrm{~m}$ zone at $O P$. Overall, the soil rutting conditions follow these sequences: dry weather: $U N B<O P<S M$; wet weather: $O P<S M<U N B$ (Figure 9).

\section{Discussion}

This article describes ways and means by which the resistance of soils to cone penetration can be analyzed and modeled at the daily level year-round, over many years, and for the varying soil conditions by select locations. The results so obtained are-apart from study-specific biases-generally consistent with what has been reported in the literature. These biases would inter alia refer to differences in $C I$ methodology by, e.g., cone dimensions, speed of cone penetration, and field versus laboratory testing [4].

While the plot-by-plot determinations of this study are limited to three contrasting forest locations, they are at least representative of how soil moisture, $C I$, and rutting depth vary by soil properties, season and topographic position, as demonstrated through daily and spatial modelling. The extent to which this 

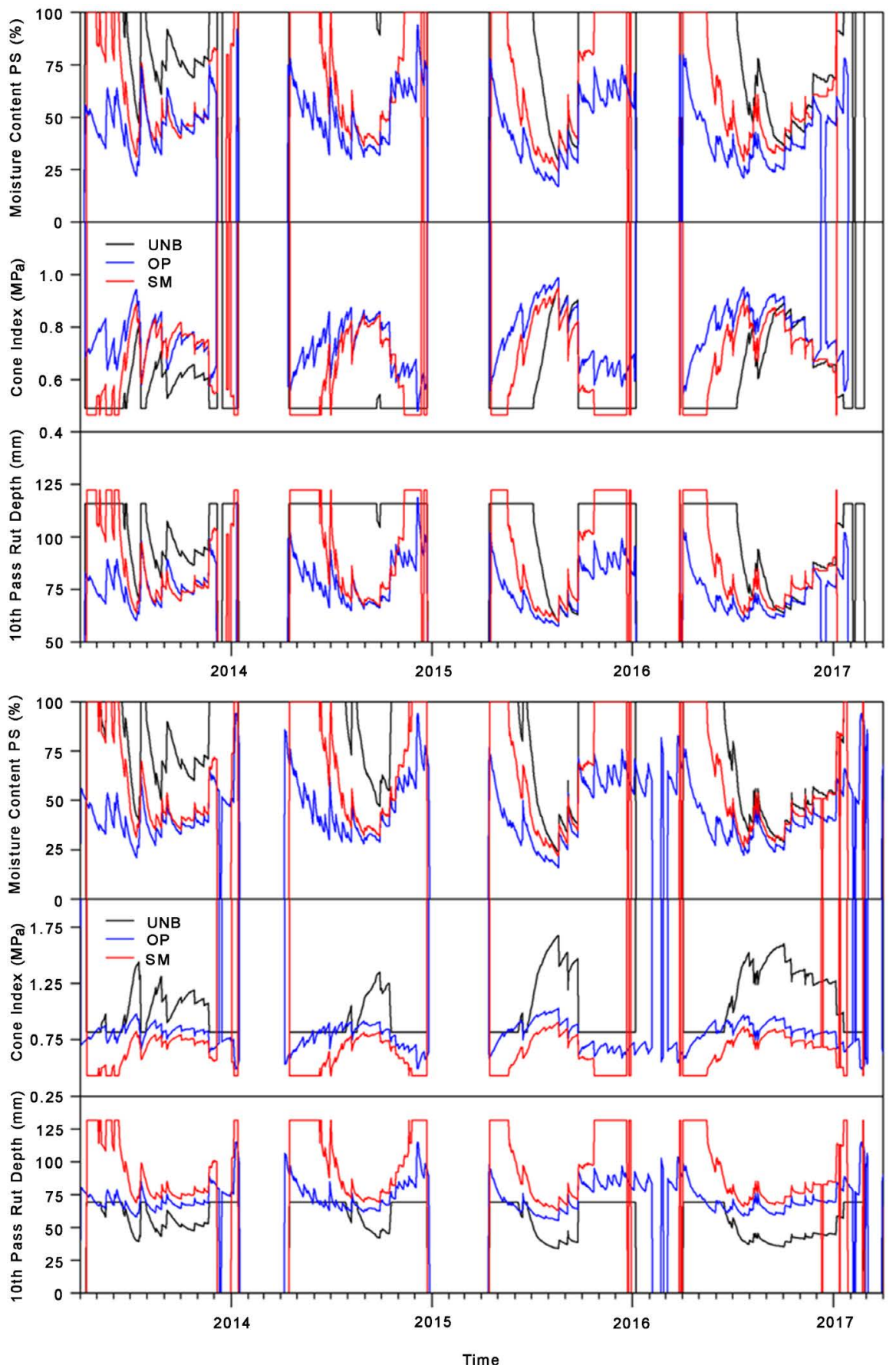

Figure 9. ForHyM-generated unfrozen $M C_{p s}, C I$, and rut depths from April 2013 to April 2017 for the topsoil (top $15 \mathrm{~cm}$ of soil) for plot 1 (top) and plot 2 (bottom) at $U N B, O P$, and $S M$.

approach can be generalized requires additional research. For example, the spatial and $D T W$-dependent soil trafficability formulation for $C I$ and rut depth should be tested across a wider range of glaciated and non-glaciated landforms. Doing so would involve extending the above regression analyses across a wider range of independently varying soil types and properties. For example, where soils are cemented because of pedogenic $\mathrm{Fe}$ and $\mathrm{Ca}$ accumulations, the approach 


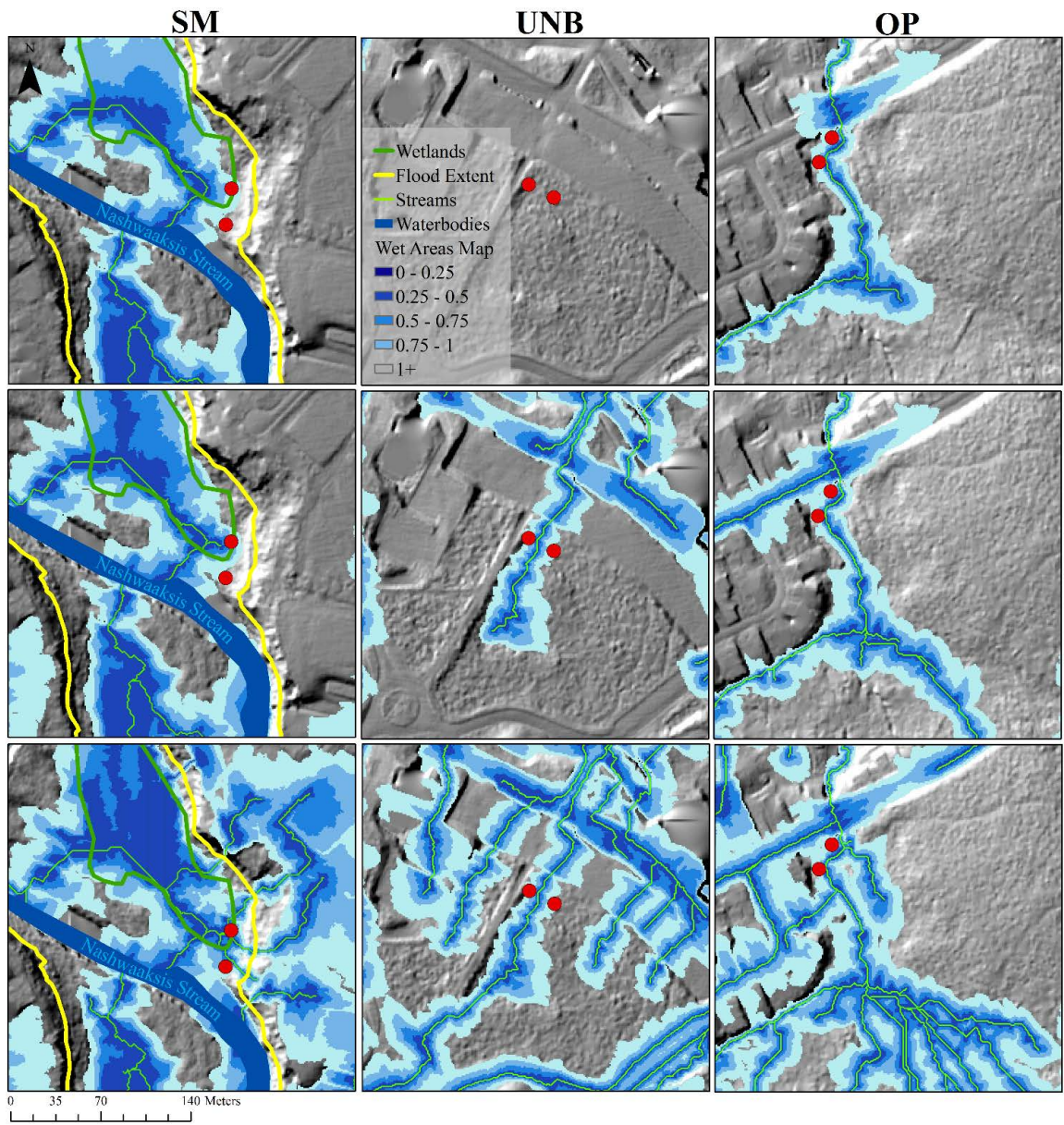

Figure 10. Cartographic depth-to-water index $(D T W \leq 1 \mathrm{~m})$, overlain on the hill-shaded LiDAR-derived bare-earth digital elevation model for the $U N B, O P$, and $S M$ locations for end-of-summer (top), spring-to-summer as well as fall-to-winter (middle), and earlyspring, as emulated using upslope stream-flow initiation areas amounting to 4,1 and 0.25 ha, respectively.

would need a cementation predictor variable. In some cases, the mix of the best-fitting regression variable and regression coefficients may also differ, as demonstrated above in Table 8.

Key to applying the approach across time and landscapes is the ability to estimate how soil trafficability changes in direct response to the spatially and temporally varying topo-pedo-hydrological conditions, meter-by-meter. Traditional soil survey maps can be helpful in this regard but only if the individual map units and borders conform to actual soil drainage contours. To this extent, further progress can be made by:

1) refining and adjusting each unit to its landform- and DEM-defining drainage position;

2) exploring how the trafficability affecting soil properties ( $M C$, texture, $C F$, $O M, D b$, depth) vary across the landscape of interest from the highest to the lowest elevation points;

3) determining the point of streamflow initiation inside each flow channel either through field observations or through DEM-based flow-initiation algorithms. 


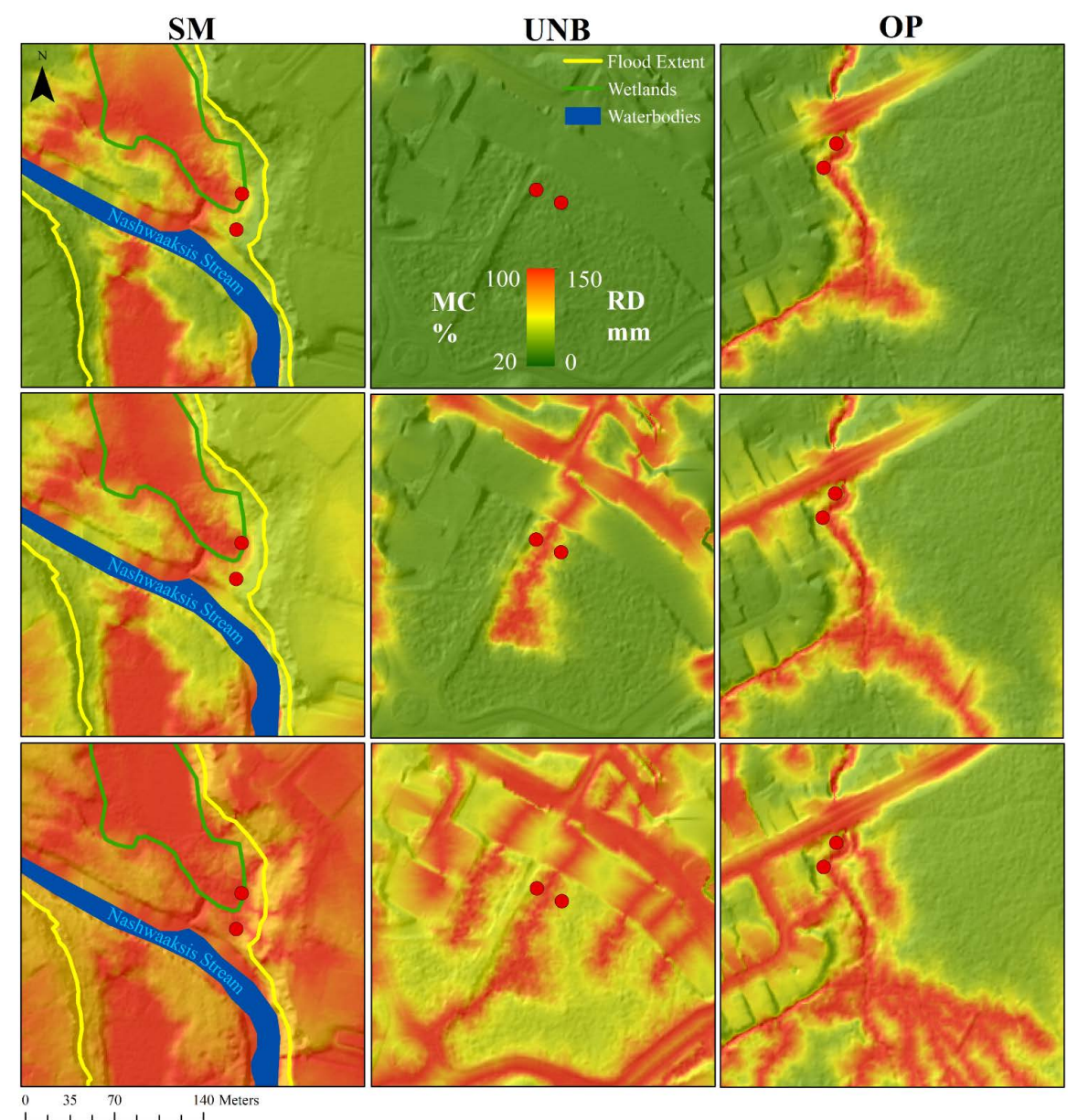

Figure 11. Soil moisture content per pore space $\left[M C_{p s}(\%)\right]$ and all-terrain rut depth after 10 passes along same track $\left(R D_{10}, \mathrm{~mm}\right)$, generated from the season-representative $D T W$ patterns in Figure 10 using Equation (7) and Equation (8). Top: end-of summer. Middle: spring-to-summer and fall-to-winter transitions. Bottom: after snowmelt.

Together, these refinements would add further precision to the soil moisture and rut depth maps in Figure 11. For example, there would be a noticeable difference between $D T W, M C_{p s}$ and $A T V$ rut depth projections within and outside the floodplain associated with the $S M$ location.

Some progress towards these refinements has already been made in terms of checking existing trail conditions in terms of $A T V$-induced rutting extent, and by correlating this extent to the ridge-to-valley of the cartographic depth-towater index $(D T W[40])$. The multi-pass implications on wood-forwarding rutting depth have been reported by [56], and were further evaluated by [4] by way of Equation (7) and Equation (8). However, much more work needs to be done by not only addressing the $D T W$-emulated variations in soil wetness but also by addressing the changes in $D_{b}$, texture, $C F$ and $O M$ content as these would vary from ridge tops to valleys in a systematic manner. For example, upslope soils would generally be thinner and coarser with less $O M$ than downslope soils. The reverse would occur in severely eroded medium-textured soils, with the more cohesive soil remains upslope and the more easily eroding sand and silt fractions 
accumulating downslope.

Since the above analysis is restricted to bare ground conditions and mineral soil layers, rut-reducing surface accumulations of snow, ice, forest litter, peat, and roots are not addressed. Bare-ground conditions, however, exist across forested landscapes along non-paved roads, after ground-exposing operations such as root extractions, mounding and plowing, and underneath forest cover where litter accumulations are low or absent due to fast litter decomposition rates. The latter condition is more prevalent under hardwood and pine forests than under fir and spruce forests. Repeated recreational traffic in such areas under moist to wet weather conditions would induce significant rut-induced damage through trail braiding, soil erosion, gulley formation, and stream and lake sedimentation [45].

Also not addressed are the effects of snow and ice build-up on top of soils during winter, which would increase the resistance to soil penetration, compaction, and rutting through increased load-bearing capacities. Since not all the water is frozen in sub-zero clay- and $O M$-enriched soils, there could be problems associated winter-based soil rutting followed by instantaneous flash freezing. In summary, the above soil rutting assessment is only applicable for bare ground conditions. Soils covered by forest litter, slash, snow, and ice would obviously reduce rutting.

\section{Concluding Remarks}

The above soil rutting assessment via manual testing of the temporal changes in the soil resistance to penetration is limited to the immediate area at and around the three sampling locations of this study. More research is needed to extend and test this research regarding general applicability. As shown, the approach taken would allow this by way of hydrological and digital elevation modelling, and further procurement of $C I$-relevant soil information.

\section{Acknowledgements}

This research was supported by a Collaborative Research Developement Project sponsored by J.D. Irving, Limited, and the Natural Science and Engineering Council of Canada. Special thanks go to Doug Hiltz, Friedrich Wüthrich, and Brittany Hartery for weekly field sampling.

\section{References}

[1] Eid, H.T. and Stark, T.D. (1998) Undrained Shear Strength for Cone Penetration Tests. In: Robertson and Mayne, Eds., Geotechnical Site Characterization, Balkema, Rotterdam.

[2] Lowery, B. and Morrison, J.E. (2002) Soil Penetrometers and Penetrability. In: Methods of Soil Analysis, Part 4. Physical Methods, Soil Science Society of America, Inc., Madison, WI, 363-385.

[3] Balland, V., Pollacco, J.A.P. and Arp, P.A. (2008) Modeling Soil Hydraulic Properties for a Wide Range of Soil Conditions. Ecological Modelling, 219, 300-316. 
[4] Vega-Nieva, D.J.D., Murphy, P.N.C., Castonguay, M., Ogilvie, J. and Arp, P.A. (2009) A Modular Terrain Model for Daily Variations in Machine-Specific Forest Soil Trafficability. Canadian Journal of Soil Science, 89, 93-109. https://doi.org/10.4141/CJSS06033

[5] Vaz, C.M.P., Manieri, J.M., de Maria, I.C. and Tuller, M. (2011) Modeling and Correction of Soil Penetration Resistance for Varying Soil Water Content. Geoderma, 166, 92-101.

[6] Lin, J., Sun, Y. and Schulze Lammers, P. (2014) Evaluating Model-Based Relationship of Cone Index, Soil Water Content and Bulk Density Using Dual-Sensor Penetrometer Data. Soil and Tillage Research, 138, 9-16.

[7] Brady, N.C. and Weil, R.R. (2008) The Nature and Properties of Soils. 14th Edition, Prentice Hall, Upper Saddle River, NJ.

[8] Kumar, A., Chen, Y., Sadek, A. and Rahman, S. (2012) Soil Cone Index in Relation to Soil Texture, Moisture Content, and Bulk Density for No-Tillage and Conventional Tillage. Agriculture Engineering International: CIGR Journal, 14, 26-37.

[9] Andersland, O.B. and Ladanyi, B. (1994) Mechanical Properties of Frozen Soils. In: An Introduction to Frozen Ground Engineering, Springer, US, 121-150. https://doi.org/10.1007/978-1-4757-2290-1_5

[10] Bronick, C.J. and Lal, R. (2005) Soil Structure and Management: A Review. Geoderma, 124, 3-22.

[11] Huntington, T.G. (2007) Available Water Capacity and Soil Organic Matter. In: Encyclopedia of Soil Science, 139-143.

[12] Culley, J.L., Dow, B.K., Presant, E.W. and Maclean, A. (1981) Impacts of Installation of an Oil Pipeline on the Productivity of Ontario Cropland. Research Branch, Agriculture Canada.

[13] Soane, B.D. and van Ouwerkerk, C. (1994) Soil Compaction Problems in World Agriculture. In: Soil Compaction in Crop Production, 1-9.

[14] Chen, G. and Weil, R.R. (2010) Penetration of Cover Crop Roots through Compacted Soils. Plant and Soil, 331, 31-43. https://doi.org/10.1007/s11104-009-0223-7

[15] Chen, G. and Weil, R.R. (2011) Root Growth and Yield of Maize as Affected by Soil Compaction and Cover Crops. Soil and Tillage Research, 117, 17-27.

[16] Gregory, J., Dukes, M., Jones, P. and Miller, G. (2006) Effect of Urban Soil Compaction on Infiltration Rate. Journal of Soil and Water Conservation, 61, 117-124.

[17] Kozlowski, T.T. (2008) Soil Compaction and Growth of Woody Plants. Scandinavia Journal of Forest Resources, 14, 596-619. https://doi.org/10.1080/02827589908540825

[18] Moehring, D.M. and Rawls, I.W. (1970) Detrimental Effects of Wet Weather Logging. Journal of Forestry, 68, 166-167.

[19] Carter, E.A., Aust, W.M. and Burger, J.A. (2007) Soil Strength Response of Select Soil Disturbance Classes on a Wet Pine Flat in South Carolina. Forest Ecology and Management, 247, 131-139.

[20] Saarilahti, M. (2002) Soil Interaction Model-Development of a Protocol for Ecoefficient Wood Harvesting on Sensitive Sites (Ecowood). Appendix Report No. 5.

[21] Affleck, R.T. (2005) Disturbance Measurements from Off-Road Vehicles on Seasonal Terrain Cold Regions Research and Engineering Laboratory. US Army Corps of Engineers, Engineer Research and Development Center, Cold Regions Research and Engineering Laboratory.

[22] Sakai, H., Nordfjell, T., Suadicani, K., Talbot, B. and Bøllehuus, E. (2008) Soil 
Compaction on Forest Soils from Different Kinds of Tires and Tracks and Possibility of Accurate Estimate. Croatian Journal of Forest Engineering, 29, 15-27.

[23] Han, H.-S., Page-Dumroese, D., Han, S.-K. and Tirocke, J. (2006) Effects of Slash, Machine Passes, and Soil Moisture on Penetration Resistance in a Cut-to-Length Harvesting. International Journal of Forest Engineering, 17, 11-24.

[24] Shoop, S.A. (1995) Vehicle Bearing Capacity of Frozen Ground over a Soft Substrate. Canadian Geotechnical Journal, 32, 552-556. https://doi.org/10.1139/t95-057

[25] Robertson, P.K. (2016) Cone Penetration Test (CPT)-Based Soil Behaviour Type (SBT) Classification System-An Update. Canadian Geotechnical Journal, 53, 19101927. https://doi.org/10.1139/cgj-2016-0044

[26] Stobbe, P.C. (1940) Soil Survey of Fredericton-Gagetown Area. Department of Agriculture, Experimental Farm Service, $51 \mathrm{p}$.

[27] Department of Environment and Climate Change Canada (2016) Historical Climate Data. http://climate.weather.gc.ca/

[28] Shelrick, B.H. and Wang, C. (1993) Particle Size Distribution. In: Carter, M.C., Ed., Soil Sampling and Methods of Analysis, Lewis Publishers, Boca Raton, FL.

[29] Arp, P.A. and Yin, X. (1992) Predicting Water Fluxes through Forest from Monthly Precipitation and Mean Monthly Air Temperature Records. Canadian Journal of Forest Research, 22, 864-877. https://doi.org/10.1139/x92-116

[30] Yin, X. and Arp, P.A. (1994) Fog Contributions to the Water Budget of Forested Watersheds in the Canadian Maritime Provinces: A Generalized Algorithm for Low Elevations. Atmosphere-Ocean, 32, 553-565. https://doi.org/10.1080/07055900.1994.9649512

[31] Jutras, M.-F. (2012) Modeling Stream Discharge in Forest Catchments across Canada: Hydraulic Conductivity Calibrations. Unpublished Master's Thesis, University of New Brunswick, Canada.

[32] Department of Environment and Climate Change Canada (2016) Historical Hydrometric Data. http://wateroffice.ec.gc.ca/

[33] Balland, V., Bhatti, J., Errington, R., Castonguay, M. and Arp, P.A. (2006) Modeling Snowpack and Soil Temperature and Moisture Conditions in a Jack Pine, Black Spruce and Aspen Forest Stand in Central Saskatchewan (BOREAS SSA). Canadian Journal of Soil Science, 86, 203-217. https://doi.org/10.4141/S05-088

[34] Jutras, M.-F. and Arp, P.A. (2010) Determining Hydraulic Conductivity from Soil Characteristics with Applications for Modelling Stream Discharge in Forest Catchments. In: Elango, L., Ed., Hydraulic Conductivity_Issues, Determination and Applications, InTech, 189-202.

[35] Jutras, M.-F. and Arp, P.A. (2013) Role of Hydraulic Conductivity Uncertainties in Modeling Water Flow through Forest Watersheds. In: Rodrigues da Silva, V., Ed., Hydraulic Conductivity, InTech, 33-54. https://doi.org/10.5772/56900

[36] Saarilahti, M. (2002) Soil Interaction Model-Development of a Protocol for Ecoefficient Wood Harvesting on Sensitive Sites (Ecowood). Appendix No. 8 Forest Soil Properties.

[37] GeoNB (2015) Bare-Earth Digital Elevation Model. Service New Brunswick, Fredericton, NB.

[38] Murphy, P.N.C., Ogilvie, J. and Arp, P.A. (2009) Topographic Modelling of Soil Moisture Conditions: A Comparison and Verification of Two Models. European Journal of Soil Science, 60, 94-109. https://doi.org/10.1111/j.1365-2389.2008.01094.x

[39] White, B., Ogilvie, J., Campbell, D.M.H., Hiltz, D., Gauthier, B., Chisholm, H.K.H., 
Wen, H.K., Murphy, P.N.C. and Arp, P.A. (2012) Using the Cartographic Depth-toWater Index to Locate Small Streams and Associated Wet Areas across Landscapes. Canadian Water Resources Journal, 37, 333-347. https://doi.org/10.4296/cwrj2011-909

[40] Murphy, P.N.C., Castonguay, M., Ogilvie, J., Nasr, M., Hazlett, P., Bhatti, J.S. and Arp, P.A. (2009) A Geospatial and Temporal Framework for Modeling Gaseous N and Other N Losses from Forest Soils and Basins, with Application to the Turkey Lakes Watershed Project, in Ontario, Canada. Forest Ecology and Management, 258, 2304-2317.

[41] Young, G.C. and Berlyn, R.W. (1968) Some Variations in Soil Trafficability as Measured with a Cone Penetrometer. Pulp and Paper Research Institute of Canada, Pointe Claire, P.Q.

[42] Busscher, W.J., Bauer, P.J., Camp, C.R. and Sojka, R.E. (1997) Correction of Cone Index for Soil Water Content Differences in a Coastal Plain Soil. Soil and Tillage Research, 43, 205-217.

[43] Carter, E., McDonald, T. and Torbert, J. (2000) Assessment of Soil Strength Variability in a Harvested Loblolly Pine Plantation in the Piedmon Region of Alabama, United States. New Zealand Journal of Forestry Science, 30, 237-279.

[44] Porsinsky, T., Sraka, M. and Stankic, I. (2006) Comparison of Two Approaches to Soil Strength Classifications. Croatian Journal of Forest Engineering, 27, 17-26.

[45] Campbell, D.M.H., White, B. and Arp, P.A. (2013) Modeling and Mapping Soil Resistance to Penetration and Rutting Using LiDAR-Derived Digital Elevation Data. Journal of Soil and Water Conservation, 68, 460-473. https://doi.org/10.2489/jswc.68.6.460

[46] Baetens, J.M., Verbist, K., Cornells, W.M., Gabriels, D. and Soto, G. (2009) On the Influence of Coarse Fragments on Soil Water Retention. Water Resources Research, 45, W07408. https://doi.org/10.1029/2008WR007402

[47] Rücknagel, J., Götze, P., Hofmann, B., Christen, O. and Marschall, K. (2013) The Influence of Soil Gravel Content on Compaction Behaviour and Pre-Compression Stress. Geoderma, 209-210, 226-232.

[48] Alexander, L. and Skaggs, R.W. (1987) Predicting Unsaturated Hydraulic Conductivity from Soil Texture. Journal of Irrigation and Drainage Engineering, 113, 184197. https://doi.org/10.1061/(ASCE)0733-9437(1987)113:2(184)

[49] Wesseling, J.G., Stoof, C.R., Ritsema, C.J., Oostindie, K. and Dekker, L.W. (2009) The Effect of Soil Texture and Organic Amendment on the Hydrological Behaviour of Coarse-Textured Soils. Soil Use and Management, 25, 274-283. https://doi.org/10.1111/j.1475-2743.2009.00224.x

[50] Manuwa, S.I. (2012) Evaluation of Shear Strength and Cone Penetration Resistance Behavior of Tropical Silt Loam Soil under Uni-Axial Compression. Open Journal of Soil Science, 2, 95-99. https://doi.org/10.4236/ojss.2012.22014

[51] Hausenbuilder, R.L. (1978) Soil Science: Principles and Practices. 2nd Edition, William C. Brown Company, Reading, PA.

[52] Krzic, M., Bulmer, C.E., Teste, F., Dampier, L. and Rahman, S. (2004) Soil Properties Influencing Compactability of Forest Soils in British Columbia. Canadian Journal of Soil Science, 84, 219-226. https://doi.org/10.4141/S03-056

[53] Šušnjar, M., Horvat, D. and Šešelj, J. (2006) Soil Compaction in Timber Skidding in Winter Conditions. Croatian Journal of Forest Engineering, 1, 3-15.

[54] Jakobsen, B.F. and Dexter, A.R. (1987) Effect of Soil Structure on Wheat Root Growth, Water Uptake and Grain Yield. A Computer Simulation Model. Soil and 
Tillage Research, 10, 331-345.

[55] Busscher, W.J., Spivey, L.D. and Campbell, R.B. (1987) Estimation of Soil Strength Properties for Critical Rooting Conditions. Soil and Tillage Research, 9, 377-386.

[56] Meek, P. (1996) Effects of Skidder Traffic on Two Types of Forest Soils. Technical Report No. TR_117, Pointe-Claire, QC.

Submit or recommend next manuscript to SCIRP and we will provide best service for you:

Accepting pre-submission inquiries through Email, Facebook, LinkedIn, Twitter, etc. A wide selection of journals (inclusive of 9 subjects, more than 200 journals) Providing 24-hour high-quality service User-friendly online submission system Fair and swift peer-review system Efficient typesetting and proofreading procedure Display of the result of downloads and visits, as well as the number of cited articles Maximum dissemination of your research work

Submit your manuscript at: http://papersubmission.scirp.org/ Or contact ojss@scirp.org 